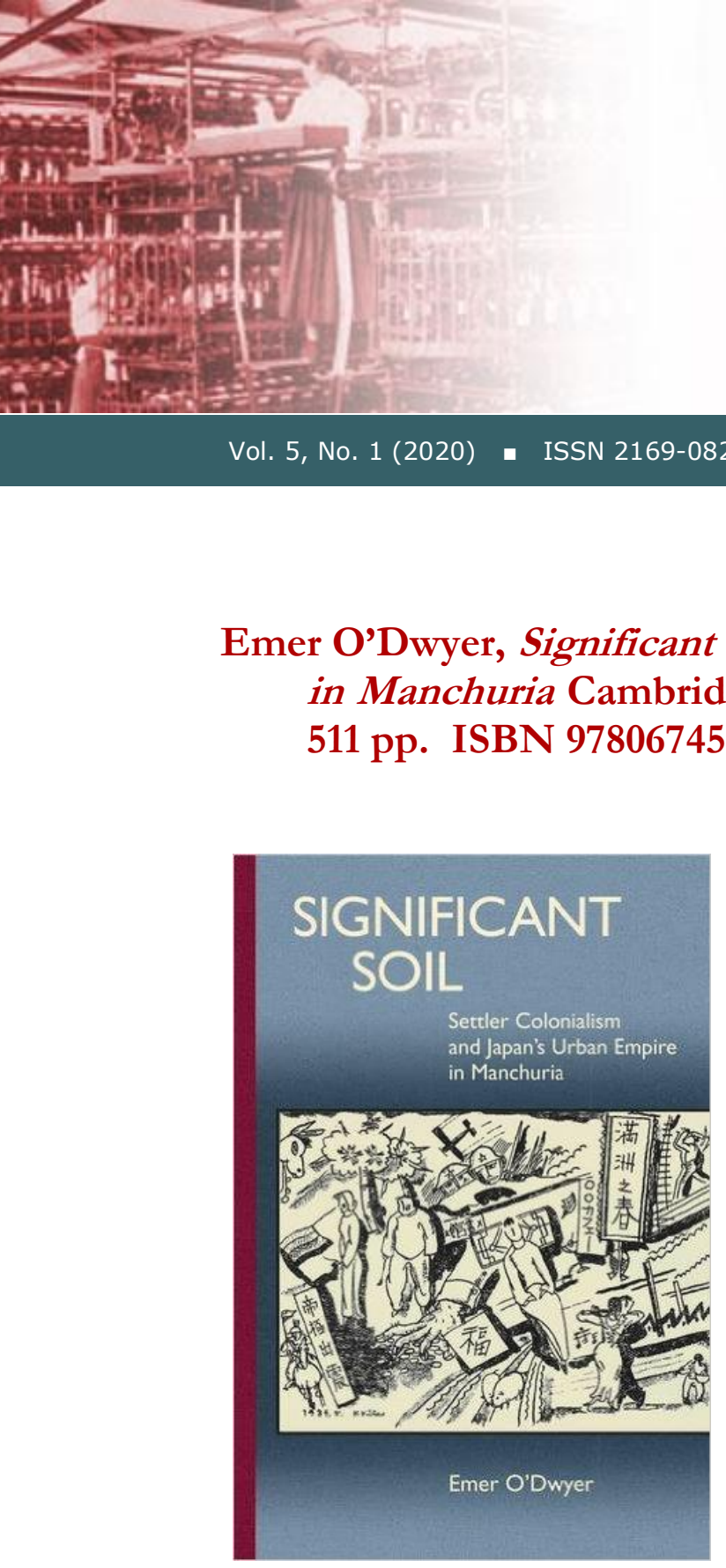

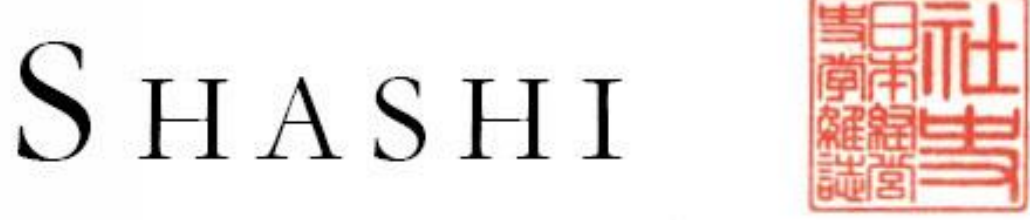

The Journal of Japanese Business and Company History

\section{Emer O'Dwyer, Significant Soil: Settler Colonialism and Japan's Urban Empire in Manchuria Cambridge. MA: Harvard University Asia Center, 2015. xv, 511 pp. ISBN 9780674504332}

In this finely crafted work, Emer O'Dwyer offers the first detailed study in English of Japan's Kwantung leasehold in South Manchuria, focusing on the "cosmopolitan oasis" of Dairen and its Japanese settler community. In many respects, the book, as the author indicates, is a study of an urban place "like no other" in the Japanese empire, a city outside of the metropole that had an exceptionally large Japanese population - around 35 percent of Dairen's total for much of the period covered - and one that developed a strong tradition of local self-governance though under the looming presence of a semi-governmental company, the South Manchuria Railway (Mantetsu). Through a granular look at the agency of Japanese settlers, especially Mantetsu employees, Significant Soil excavates ground only lightly surveyed by other studies, including the two most important works to date on pre-1940 Manchuria, Japan's Total Empire (1998) by Louise Young and The Making of Japanese Manchuria (2001) by Tak Matsusaka. In doing so, the book joins recent work on Japanese settlement in other parts of the empire such as Jun Uchida's Brokers of Empire: Japanese Settler Colonialism in Korea (2011) and Steven Ivings' "Colonial Settlement and Migratory Labour in Karafuto" (Ph.D. dissertation, 2014).

We previously knew that, even after 1932, the Kwantung Leasehold "enjoyed a more tolerant political climate than other Japanese colonies" (John Stephan, “Guangdong [Kwantung] Territory,” Kodansha Encyclopedia of Japan), but O'Dwyer shows concretely just how that climate emerged in the preceding decades and persisted into the 1930s. From 1905 to 1937, she writes, Japanese residents of the leasehold — especially its major city, Dairen — "acted with determination and initiative to shape local governance such that the leasehold [would] occupy a prominent place in Japan's expanding empire" (p. 4). Authorities in Tokyo and Port Arthur supported the extension of civilian selfgovernance in Dairen, including the granting of a municipal code like those of metropolitan cities, to bolster Japan's claim to South Manchuria. Settlers, however, played a large part in the process by striving to make their city comparable - even superior in modernity - to its metropolitan cousins. This effort included sending frequent missions to petition Tokyo officials and engaging in "absentee parliamentarianism" whereby residents would win election to the Japanese Diet after registering through their native districts in the home islands. (In 1930 the leasehold and railway zone, 44 percent of whose Japanese population lived in Dairen, accounted for 19 Diet seats compared to 31 for Tokyo, more than quintupling Tokyo's per capita representation in the Diet [p. 47]). 
Another key contribution O'Dwyer makes is to highlight the critical role of Mantetsu's Dairen-based employees in transforming the social and political life of the leasehold during the 1920s. Through extensive use of Mantetsu employee journals, she documents the ways in which the employees- "especially those steeped in currents of Taishō democracy" (p. 166) who joined the firm in growing numbers as Mantetsu markedly expanded its operations after World War I — organized to reinforce Dairen's civil society and liberal governance traditions and preserve them into the 1930s. The journals enable O'Dwyer to give voice to the thousands of rank-and-file workers, in particular the nearly twenty thousand members of the Mantetsu Employees Association, actors who are largely absent in Matsusaka's seminal work.

I found O'Dwyer's revisionist discussion of developments involving the leasehold and Mantetsu during and after the Manchurian Incident of 1931-1932 particularly striking. The "war fever" that Young describes was clearly present among Mantetsu employees and other settlers at the outset of the incident. O'Dwyer interestingly maintains that the Incident "would have remained an 'affair,' or even merely a skirmish, if not for the thoroughgoing operational and financial support provided by Mantetsu" in the early weeks of fighting (p. 280). In contrast to Young's claim regarding broad Japanese support for “total empire," however, O’Dwyer points out that before long the Kwantung Army faced determined opposition from Japanese residents to its encroachment on leasehold institutions and traditions of civilian self-rule and that the continental empire was never in fact "total": Tokyo never transferred sovereignty over the leasehold to the puppet state of Manchukuo, and leasehold residents retained their extraterritorial privileges, immune from taxation or policing by Manchukuo authorities. Not until 1934 did the Kwantung Army finally succeed in placing civilian rule in the leasehold under its supervision. According to O'Dwyer, therefore, the "rocky transition" (p. 315) to wartime imperialism in South Manchuria suggests the need to revise the standard periodization that sees the Manchurian Incident as "the decisive dividing line between two stages of Japanese imperialism" (p. 278).

To some extent, O'Dwyer redresses the lack of attention given to the resident Chinese population in previous scholarship on Japanese Manchuria. She briefly profiles Dairen's privileged native business elite who comprised roughly two percent of resident Chinese in 1923, and she also describes the less desirable parts of the city populated by the Chinese laboring classes. To cultivate Chinese goodwill, she notes, the Kwantung authorities reserved appointive positions on the Dairen Municipal Council for prominent Chinese residents. Over time, however, the city's touted "Japanese-Chinese amity" became strained, especially from the early 1920s, as the Kwantung authorities and Japanese settlers increasingly pushed to make Dairen "as Japanese as possible" (p. 162). Despite offering glimpses of Chinese agency, O'Dwyer states that not only are the voices of native laborers "obscured" but even those of the Chinese city councilors are "impossible to judge from the historical record" (pp. 57, 346).

O’Dwyer concludes with a lively comparison of Dairen and Shanghai. Each city functioned as a cosmopolitan "gateway to Asia" and featured "a socially mixed settler society and a large Chinese underclass" as well as "a thriving commercial culture" (p. 354), though the contrasts included, in the case of Dairen, a far greater percentage of nonChinese (specifically Japanese) residents and the heavy involvement in governance of a semipublic Japanese enterprise. The author might have brought out more fully the distinctiveness of "semicolonial" Dairen within the Japanese empire by comparing it with competing colonial cities such as Pusan, which in the mid-1910s had threatened to displace Dairen as the "pivot point of the empire" under Terauchi Masatake's plan to make the Pusan-Fengtian railway route Japan's principal feeder line on the continent (p. 75). O'Dwyer might also have provided a fuller picture of the "urban empire" in South Manchuria by providing more detail on how Port Arthur was "all about governance" and Dairen "all about business" (p. 356).

Despite what the author might have done in the way of further comparisons, her elegantly written book offers fresh and compelling insights into Japan's early twentieth-century empire. As a history "from below" and "from within," it contributes to the growing literature that complements and extends the elite- and metropole-centered studies 
of the past. I will happily assign chapters, particularly the two that complicate our understanding of the early to mid1930s, in my undergraduate courses on modern Japan and on imperialism in modern East Asia.

\section{Steven J. Ericson \\ Dartmouth College}

\section{(c) $)$ EY}

New articles in this journal are licensed under a Creative Commons Attribution 3.0 United States License.

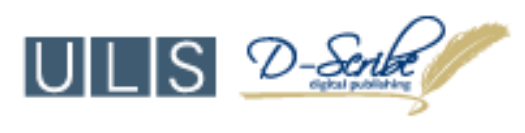

This journal is published by the University Library System, University of Pittsburgh as part of its D-Scribe Digital Publishing Program and is cosponsored by the University of Pittsburgh Press. 